\title{
Abstract and Concrete Representations in Structure-Mapping and Class-Inclusion
}

\author{
Hassan Banaruee \\ Chabahar Maritime University, Iran \\ Submission: January 11, 2017; Published: January 23, 2018 \\ *Corresponding author: Hassan Banaruee, Chabahar Maritime University, Iran; Email: hassan.banaruee@gmail.com
}

\section{Short Communication}

In their article, Khatin Zadeh, Vahdat [1] discuss two influential theories of metaphor comprehension: the structuremapping and the class-inclusion. Khatin Zadeh and Vahdat start their article by presenting a detailed description of Gentner's [2] structure-mapping theory. They do this by discussing several examples of analogy. Khatin Zadeh and Vahdat suggest that the process of analogy between two concretely different systems of relations takes place through the mediation of an abstract system of relations. They emphasize the critical role that this abstract system of relations plays in the process of mapping one domain into another domain. They suggest that this abstract mediating system of relations is formed by the suppression of concrete features of base domain. Then, this abstract system of relations receives the concrete features of target domain. Therefore, it seems that this description of analogy includes the two stages of suppression and reception. In the initial stage of suppression, the concrete features of base domain are removed, resulting in the formation of an abstract system of relations among a set of abstract elements.

In the following stage of reception, the concrete features of target domain are added to abstract system. However, Khatin Zadeh and Vahdat do not present a detailed description of these two stages that might be involved in the process of analogy. In the following sections of their article, Khatin Zadeh and Vahdat discuss the class-inclusion model $[3,4]$ of metaphor comprehension. After discussing this theory, they present a model for the creation of metaphorical classes. They suggest that metaphorical classes are formed on the basis of a single salient semantic feature. In fact, this feature can be considered as the defining feature of the metaphorical class. Khatin Zadeh and
Vahdat propose that the main difference between metaphorical classes and literal classes is that every metaphorical class is defined by a single salient feature.

On the other hand, a literal class is defined by a large set of semantic features. Therefore, while a metaphorical class can be seen as a broad category that may include concretely-different members, a literal class is seen as a specific category of members that are very similar to each other in terms of concrete features. The model proposed by Khatin Zadeh and Vahdat is novel because it presents a new definition for literal and metaphorical classes. This model has been elaborated on in another article by Banaruee et al. [5]. In their article, the authors have looked at this model on the basis of findings from some neuropsychological studies. It seems that the model suggested by Khatin Zadeh and Vahdat accompanied by the findings of several studies in neuropsychology can provide an effective model for describing the process of metaphor comprehension in general, and creation of metaphorical classes in particular.

\section{References}

1. Khatin Zadeh O, Vahdat S (2015) Abstract and concrete representations in structure-mapping and class-inclusion. Cognitive Linguistic Studies 2(2): $349-360$

2.Gentner D (1983) Structure-mapping: A theoretical framework for analogy. Cognitive Science 7(2): 155-170.

3.Glucksberg S (2003) The psycholinguistics of metaphor. Trends in Cognitive Sciences 7(2): 92-96.

4.Glucksberg S, Keysar B (1990) Understanding metaphorical comparisons: Beyond similarity. Psychological Review 97(1): 3-18.

5. Banaruee H, Khoshsima H, Khatin Zadeh O, Askari A (2017) Suppression of semantic features in metaphor comprehension. Cogent Psychology $4(1): 1-6$ 
This work is licensed under Creative Commons Attribution 4.0 License

\section{Your next submission with Juniper Publishers will reach you the below assets}

- Quality Editorial service

- Swift Peer Review

- Reprints availability

- E-prints Service

- Manuscript Podcast for convenient understanding

- Global attainment for your research

- Manuscript accessibility in different formats

( Pdf, E-pub, Full Text, Audio)

- Unceasing customer service

Track the below URL for one-step submission https://juniperpublishers.com/online-submission.php 